\title{
Impacts of teachers' time management on secondary school students' academic performance in Ekiti State, Nigeria
}

\author{
G. M. Kayode, J. B. Ayodele \\ Department of Educational Foundation and Management, Faculty of Education, Ekiti State University, Ado-Ekiti, Nigeria
}

Email address:

gladys.kayode@eksu.edu.ng (G. M. Kayode), tolayodele@yahoo.co.uk (J. B. Ayodele)

To cite this article:

G. M. Kayode, J. B. Ayodele. Impacts of Teachers' Time Management on Secondary School Students' Academic Performance in Ekiti State, Nigeria. International Journal of Secondary Education. Vol. 3, No. 1, 2015, pp. 1-7. doi: 10.11648/j.ijsedu.20150301.11

\begin{abstract}
This study examined the impact of teachers' time management on secondary school students' academic performance in Ekiti State, Nigeria. The sample for the study was 500 secondary school teachers and 50 school registrars who were selected using simple random sampling technique. An instrument tagged 'Questionnaire on Secondary School Teachers' Time Management in Ekiti State, Nigeria' (QSSTTM) was used to interview the teachers and the second instrument is an Inventory on Senior Secondary School Certificate Examination results obtained from the registrars. Face and content validity were used to ascertain the validity of the instruments. The Split half method was used to ascertain the reliability of the instrument and found to be 0.82 for QSSTTM. The data collected were analyzed using percentage, mean, standard deviation and Pearson's Product Correlation Analysis. All the hypotheses were tested at 0.05 level of significance. The findings revealed that there was a significant relationship between teachers' time management and students' academic performance. The level of teachers' time management and academic performance was moderate. It was therefore recommended that teachers should improve upon their time management, especially by being more conscious about how to control their time.
\end{abstract}

Keywords: Teachers' Time Management, Secondary School, Students' Academic Performance, Ekiti State Nigeria

\section{Introduction}

In Nigeria, as in other parts of the world, educational system is examination oriented. Thus the quality of education could be adjudged by secondary school students' academic performance in the National School Leaving Certificate Examinations. These examinations, known as Secondary School Certificate Examinations, are conducted by the West African Examinations Council (WAEC) and the National Examination Council (NECO). There is now a growing concern on the factors that influence students' academic performance in these examinations.

In recent times, students' academic performance in these national examinations had declined in Ekiti State. Results showed that between 2006 and 2008, only 28\% of the students who attempted English Language, 42\% Yoruba Language, 28\% Biology, 51\% Mathematics and 43\% Economics in WAEC were successful (Ministry of Education, Science and Technology, 2011). Previous studies revealed that several factors such as student's internal state of mind, intelligence, health status, anxiety, teacher's motivation and environment had been found to impact students' academic performances. Teachers' time management could also influence students' academic performance. Unfortunately, this factor has been neglected in Nigeria thus this factor has not been examined.

Time is a resource that affects all aspects of human endeavours. It is a resource that is extremely limited in supply and it is a factor that affects all stakeholders in educational sector - students, teachers, administrators, supervisors etc. According to Ekundayo, Konwea \& Yusuf (2010), instances now abound where teachers complain of lack of time to do certain things which they would have done. A good teacher must make effective use of his time to have time for everything he plans to do. Olaniyi (1998) opined that the most important asset a teacher should possess is the skill in managing his time. Such skill will enable the teacher to devote a balanced attention to interpersonal relations and production (Ekundayo et. al. 2010). In a previous assertion, Naglieri and Gottling (1997) stated that a maximization of the use of time for academic activities is required to enhance students' academic performances and attitudes. Thus this study investigates the 
impact of secondary school teachers' time management on students' academic performance in Ekiti State, Nigeria.

\section{Literature Review}

Students' academic performance refers to how students deal with their studies and how they cope with or accomplish different tasks given to them by their teachers. It is the ability to study and remember facts and being able to communicate the knowledge verbally or down on paper. Thus, academic performance is the outcome of education, that is, the extent to which a student, teacher or institution has achieved their educational goals. The secondary education is known to occupy a strategic position in Nigerian education system (Akinsanya, 2008). It serves as a link between primary and higher education by absorbing the products of the former and supplying entrants into the latter. In recent years, the performances of secondary school students in national examinations conducted by the West Africa Examination Council and NECO were extremely poor (Imoge 2002, Ashibi 2005, Ikoh 2007, Tenibiaje 2009, Ayodele and Ige 2012). Thus, the investigations of the factors that influence academic performance of secondary school students have attracted the attention of relevant stakeholders including parents, guidance, teachers, counselors, psychologists, school administrators, governments and researchers.

A number of factors have since been identified to be capable of influencing the academic performance of secondary school students in Nigeria (Fabunmi and Okorie 2000, Fabunmi, BraiAbu and Adeniji, 2007). Such factors, according to Eweniyi (2002) may be the student's internal state of mind, intelligence, state of health, anxiety, teacher's motivation etc. and their environment (availability of suitable learning environment, adequacy of educational infrastructure like textbook, library and well equipped laboratories). Clemens and Deike (1967) had earlier attributed the cause of poor academic performance to a combination of personal and institutional factors. While the personal factor relate to individual intelligence, knowledge and ability, the institutional influences school related factors teacher/student rapport, teacher related factors, accommodation and living conditions. Similarly, Wiseman (1973) had identified a number of factors that causes poor academic performances among secondary school students to include intellectual ability, poor study habit, achievement motivation, lack of vocational goals, low self-concept, low socio economic status of the family, poor family structure, anxiety, indiscipline in schools and low level of educational standard. Tomul and Savasci (2012) as well as Savaci and Tomul (2013) also stressed the importance of socio-economic factors as prerequisites to academic performance. Card and Krueger (1996), Greenwald, Hedges and Laine (1996), Fuller and Clarke (1994) and Heyneman and Loxley (1983) asserted that physical and economic resources affect academic performance.

Studies by Nzewuawah (1995), Ajila and Olutola (2000), Eweniyi (2002) and Tenibiaje (2009) also asserted that family structure has an impact on academic performance.
Ajila and Olutola (2000) asserted that the home has a great influence on the student's psychological, emotional, social and economic state. They contended that the state of home affects the individual since the parents are the first socializing agents in an individual's life. Eweniyi (2002) in enumerating the importance of home to child development asserted that the family background and context of a child affects his reaction to life situations and his level of performance. Hence, the home play tremendous roles in building the personality of the child and in making the child what he is. Thus, Ichado (1998) asserted that the environment in which the student grows up can greatly influence his performance in the school.

Ushie, Emaka, Ononga and Owolabi (2012) opined that parental socioeconomic background is another determinant of students' academic performance. They concluded that a lack of seriousness, consciousness, determination and discipline on the part of most students resulted in their poor performances in examinations.

Studies by Ibi (2002) and Kida (2004) revealed that factors that cause low academic performance by students at secondary school certificate examination (SSCE) in Nigeria were mostly connected with supply and utilization of human and material resources. Egungun (1992), Obayan (2003), Iyanmu (2005) and Darling-Hammond (2005) asserted that the quality of an educational system depends on the quality of the teachers. Ayodele and Oyewole (2012) described teachers as the main determinant of quality in education. They constitute a major drive in the production process and in the determination of the output (Oyewole 2008). A nation where teachers are apathetic, uncommitted, uninspired, lazy, unmotivated, immoral, antisocial, such nation is doomed. Hanushek (1997) reported positive effects of student-teacher ratio, educational materials, library size and teacher education on learning outputs. Other studies revealed that class size (Lindahl 2005), teachers' qualification (Riskin, Hanushek and Kain, 2005), teachers' length of service (Demir 2009) and teachers attitude (Adesoji 1999) affects students' academic performance. Adesola (2005), Ahievbolaria (2005), Akinfolarin (2008), Ayodele and Abiodun (2008), Achibong and Nja (2011), Ayodele and Ige (2012) opined that effective utilization of teachers impacts students' academic performance.

Similarly, Ajila and Olusola (2000) reported that the causes of poor performances in examinations of the West Africa Examination Council had been examined by Daily Sketch publication in 1986. In this publication, the causes of poor academic performances were identified and categorized as problems by teachers, problems of inadequate facilities in the schools, problem traceable to students, problems caused by parents and societies at large and problems of government policies and funding of education. Akinwonmi (2006) asserted that some of the resources that affect students' academic performance were grossly inadequate and thus constituted severe challenges to educational goal of the school system. One of these resources is time management especially by teachers. Teachers' time management has significant impacts on students' academic performance though little or no investigation has been carried out on this 
in the country. Nwadiani (1999) asserted that in Nigeria, students in both primary and secondary schools are guided by teachers and by their parents (home) to use time by providing guidelines for time management. While teachers provided major guidance in instructional time management, the home provides major guidance in the non-instructional time management. Thus while a large number of studies previously conducted in Nigeria have concentrated on the impacts of the factors enumerated above, the impacts of teachers' time management have been neglected.

\section{Statement of the Problem}

In recent times, performance of secondary school students in Ekiti state in national examinations has been declining since 2006. The performance of secondary school students in examinations conducted by the West African Examinations Council (WAEC) between the year 2006 and 2008 was examined. The expected performance for a candidate to be considered successful in WAEC examinations is a minimum of five credits in the core subjects of Biology, Economics, English Language, Mathematics and Yoruba.

However, in Ekiti State, students' academic performance has been declining despite the fact that public secondary schools in the state are assumed to have adequate and well trained teachers, well qualified pupils from primary schools, and fairly efficient supervisory system. Thus the factor(s) responsible for the declining students' academic performance cannot be detected without focused investigation.

The issue of declining academic performance in examinations signifies a critical impediment in any country since education is a major contributor to economic growth. Thus, teachers' time management is an important input to students' academic performance. It is universally recognized that the teacher is the key person in an education system. The teacher is a major limiting factor in the classroom. Not only do his character, personality and competence play a large part in determining the atmosphere of the lesson, the sort of relationships which exist, the styles of communication and the rules and regulations governing the formalities affect his students' performances. The teacher also performs a key role in influencing the students' view of himself, his use of time and the sort of progress he/she makes.

Quite often, teachers fail to make proper planning of their time, tasks are often not performed according to levels of priority, lessons and events are ill scheduled, and at times teachers procrastinate on events. All these might have negative impact on the students' academic performances.

Consequently the following question was raised:

Is there any relationship between teachers' time management and students' academic performance in secondary schools in Ekiti State?

\section{Purpose of the Study}

The study examined the impacts of teachers' time management on secondary school students' academic performance. It also considered the relationships between teachers' time planning, time organizing, time coordinating, time directing and time controlling on students' academic performance in secondary schools in Ekiti State.

\section{Research Design}

A descriptive research using a survey was adopted in this study. Descriptive research was considered appropriate because, it focuses on observation and perception of the existing situation, describes and interprets the issues, conditions, practice or relationship that exist; views, belief and attitude that are held, processes that are going on and trends that are developing. The study therefore, describes the existing phenomena in order to highlight their relevance to given situation without manipulation of variables.

A survey research studies a small sample from a large population from where inferences would be drawn about the characteristics of the defined population. This research design conforms to the characteristics of the survey research described above. Therefore, the survey research provides conceptual and methodological design for investigating the problem of the study.

\subsection{Population}

The population consists of 4,101 teachers in 176 public secondary schools located in the 16 Local Government Areas of Ekiti State. Students' enrolment in these schools is 41, 054 (Ekiti State Ministry of Education, Science and Technology, 2011).

\subsection{Sample and Sampling Techniques}

The sample consists of 500 respondents (teachers) selected from 50 schools in Ekiti State. Simple random and purposive sampling techniques were used to select the sample for this study. The stages are summarized below.

Stage 1: 3 schools were randomly selected from the 16 Local Government Area of Ekiti State using simple random technique.

Stage 2: Purposive sampling technique was used to select 1 extra school each from Ikere Local Government and Ado Local Government Areas because of the population density of the two areas.

Stage 3: 10 teachers were randomly selected from each of the 50 schools selected for this study.

The registrar of each of the school selected was used as the respondent for the inventory on students' academic performance.

\subsection{Research Instruments}

Two sets of instruments were used in this study. The first instrument is a questionnaire tagged "Questionnaire on Secondary School Teachers' Time Management” (QSSTTM) and the second instrument is an Inventory on Senior Secondary School Certificate Examination (SSCE) results. The QSSTTM was used as instrument to collect information 
from the teachers while the Inventory was used to collect data on students' academic performance in the sampled schools.

The first instrument contains two sections. Section A of QSSTTM gathers information on instruction and bio-data of the respondents while section B seeks information on areas of teachers' time management, such as planning, organizing, coordinating, directing and controlling. A Likert 4 scale of preference was used as follows: Strongly Agree (SA), Agree (A), Disagree (D) and Strongly Disagree (SD).

The second instrument consists of two sections. Section A of the Inventory collects information on the School while Section B gathers information on the students' academic performance.

\subsection{Validity of the Instruments}

The face and content validity of the instruments were ensured by assessing the instruments through facial appraisal to ascertain their claims. Similarly, the content validity was ascertained through corrections and comments by three Lecturers in the Department of Educational Foundations and Management, Ekiti State University, Ado-Ekiti who are authorities in this area of study. The questionnaire items were constructed such that they were related to the questions in order to ensure that the research questions were well covered.

\subsection{Reliability of the Instruments}

To ensure the reliability of the instrument, the instrument was first administered to the respondents who were outside the sampled schools. The set of even numbered items were correlated with the set of the odd numbered items using split half method to calculate reliability of half of the length of the test. The full length reliability co-efficient determination was determined using the Spearman Brown formula which gave reliability co-efficient of 0.82 , which is high enough to make the instrument adequate for use.

\subsection{Administration of the Instruments}

The instruments were administered on the respondents. Data were obtained from these instruments by the researcher. The researcher made use of research assistants, who were teachers, each holding a minimum academic qualification of
Bachelor's Degree. One research assistant was selected in each school. All the research assistants were under the supervision of the researcher throughout the duration of the study. The research assistants were responsible for the administration and collection of the instruments from the respondents.

\subsection{Data Analysis}

The data collected from the questionnaires were analyzed using frequency, percentages, bar chart and graph while the hypothesis was tested using t-test and multiple regressions at 0.05 level of significance.

\section{Results and Discussion}

The study revealed that teachers' overall time management was moderate. Table 1 reveals that $13.6 \%$ of teachers' time management was low, 68.4 moderate and 18\% high. The study agreed with Omojola (2010) who had earlier observed that moderate use of time exists among some other major stakeholders in education in Ekiti State. Gerard (2002) asserted that time management can improve efficiency, effectiveness and eliminate stress.

Table 1. Descriptive analysis on the level of time utilization of teachers in Secondary Schools.

\begin{tabular}{lll}
\hline Level of Time Management & Frequency (f) & Percentage (\%) \\
\hline Low & 68 & 13.6 \\
Moderate & 342 & 68.4 \\
High & 90 & 18.0 \\
Total & 500 & 100.0 \\
\hline
\end{tabular}

In Nigeria, the minimum pass mark obtainable in secondary school leaving examination is five credit passes. Table 2 reveals that students' academic performance in Ekiti State was low as $43.6 \%, 46.8 \%$ and $44.3 \%$ of the candidates examined obtained five credits in the West Africa Examination in 2005/2006, 2006/2007 and 2007/2008 sessions respectively. Ofoegbu (2004) had earlier indicated that low performance of students in public examination is an indication that schools in Nigeria are fast decaying.

Table 2. Descriptive analysis on Academic performance of secondary school students.

\begin{tabular}{|c|c|c|c|c|c|c|c|}
\hline \multirow{3}{*}{ Year } & \multirow{3}{*}{ No. of Registered Students } & \multicolumn{6}{|c|}{ Students' Academic Performance } \\
\hline & & \multicolumn{2}{|c|}{5 Credits \& Above } & \multicolumn{2}{|c|}{4 Credits } & \multicolumn{2}{|c|}{ Less than 4 Credits } \\
\hline & & $\mathbf{N}$ & $\%$ & $\mathbf{N}$ & $\%$ & $\mathbf{N}$ & $\%$ \\
\hline $2005 / 2006$ & 4331 & 1871 & 43.6 & 1064 & 24.8 & 1396 & 32.5 \\
\hline $2006 / 2007$ & 4019 & 1881 & 46.8 & 904 & 22.5 & 1234 & 30.7 \\
\hline $2007 / 2008$ & 4130 & 1836 & 44.3 & 991 & 23.9 & 1303 & 31.4 \\
\hline
\end{tabular}

The study further revealed (Table 3) that teachers' time controlling has had the highest influence on students' academic performance with a beta weight of $0.818(81.8 \%)$. This implies that teachers will be more efficient and effective if they control their time effectively. The study also indicated that teachers' time planning is the next predictor of students' academic performance with a beta weight of 0.679 (67.9\%). This implies that teachers' time planning would complement time controlling in influencing students' academic performance in secondary schools. 
Table 3. Multiple Regression of Components of teachers 'time utilization and students' academic performance

\begin{tabular}{|c|c|c|c|c|c|c|c|c|c|}
\hline Model & B & Std Error & Beta & $T$ & Sig. T & $\mathbf{R}$ & $\mathbf{R}^{2}$ & $\overline{A d j} R^{2}$ & $\mathbf{F}$ \\
\hline Constant & 2.00 & .066 & & 30.086 & .000 & \multirow{6}{*}{.530} & \multirow{6}{*}{.281} & \multirow{6}{*}{.181} & \multirow{6}{*}{.274} \\
\hline Controlling & .022 & .008 & .813 & 2.928 & .005 & & & & \\
\hline Planning & .054 & .033 & .679 & 1.644 & .107 & & & & \\
\hline Directing & .010 & .009 & .362 & 1.125 & .267 & & & & \\
\hline Organising & .010 & 017 & .205 & .554 & .582 & & & & \\
\hline Coordinating & .001 & .001 & .170 & 1.140 & .261 & & & & \\
\hline
\end{tabular}

The study found out that there was a significant relationship between teachers' time management and students' academic performance in secondary schools. This implies that teachers must be mindful of how they manage their time. Ferguson (2010) opined that students are likely to engage more deeply and master their lessons more thoroughly when their teachers managed their resources effectively, clarify complex ideas, challenge them to work hard and think hard, deliver lessons in captivating manner and make learning coherent.

The study also revealed that there is a significant relationship between teachers time planning and students' academic performance in secondary schools. This tends to support the assertion of Pollard (2006) who opined that good planning underpins flexibility and provide the teacher with structure and security. The plan of a lesson includes formulation of concise and feasible learning objectives, organization of content and technical language of instruction.

Time planning enables a teacher to plan ahead. Achunimn, and Irondi (1998) opined that planning ahead is very vital to effectiveness. Also planning makes execution very easy and improves the use of time. Heller and Hindle (1998) in Greenwait (2002) observed that every time planned make execution of tasks much easier. Similarly, these findings reflect the views of Ajayi and Ayodele (2002) who described planning as one of the elements of management which is seen as a process of deciding in advance what to be done in such a manner that tasks are executed at minimum risk of failure or problem. Ajayi and Ayodele (2001) have earlier observed that failure to plan gives rise to in-effectiveness, undirected action and waste of resources. Fiore (2006) also concluded that planning is highly relevant to effectiveness. Achurine and Irondi (1998) enumerated the consequences of poor time planning on effectiveness to include increase in misunderstanding and confusion, lack of direction, lack of purpose and commitment, frequent stampede or panic measures to beat deadlines, conflicts in schedules and lack of self-realization.

The study revealed that there was significant relationship between teachers' time organizing and students' academic performance in secondary schools. Ajayi and Ayodele (2002) had earlier opined that organizing is a pre-requisite towards the achievement of a goal. Ukeje et al (1992) also believed that organizing is a pre-requisite to effective implementation of a plan. Indeed, Bickerstiff (1977) opined that organizing entails arrangements of students within a classroom, thus, affecting teaching-learning process. Thus, organizing is a critical factor at every point in the teaching process including planning, assessing and diagnosing, task setting, questioning, explaining and giving feedbacks.

The study also showed further that there was a significant relationship between teachers' time coordinating and students' academic performance in secondary schools. Previous study by Ukeje et. al. (1992) opined that coordinating unify and harmonize all activities aimed at achieving a task such as time management. Oluwatayo and Adebule (2012) asserted that a teacher, who appears in the classroom uncoordinated, ruffled and harsh, may scare the learners and destroy the garment of teaching and learning process.

The study revealed that there is a relationship between teachers' time directing and students' academic performance in secondary schools. This submission supports the assertion of Edem (1987) who stated that directing enhances the making of right decisions. Teachers who direct their time are able to see ahead of others, set priorities and planned their time based on the priorities set.

The study also revealed that a significant relationship exists between teachers' time controlling and students' academic performance in secondary schools. Learning process is better achieved when teaching is carried out in conformity with established rules and regulations. This finding is in agreement with Edem (1987) and Ukeje et al (1992).

In conclusion, the study showed that the predictor variable (time management) contributes to the dependent variable (students' academic performance). This could be attributed to the fact that teachers who managed their time were skewed towards better teaching delivery and thus influenced academic performances of their students. This supports the assertion of Thomas and John (1977) that goals could be achieved by efficient management of resources such as time. The study also confirm the assertion of Ibukun, Akinfolarin and Alimi (2011) that time, like space, and other physical facilities, are another contributors to perceived students' learning outcome, such as academic performance. Improvement in secondary school students' academic performance should be a major priority in the quest for the development of a virile education system. Asikhia (2010) opined that secondary education is supposed to be the bedrock and foundation towards higher knowledge in tertiary institution. Secondary education is an investment as well as an instrument that can be used to achieve a rapid economic, social, political, technological, scientific and cultural development in the country. 


\section{References}

[1] Achunine, R. N. and Irondi, E.O. (1998). Management and administration of Secondary Education in Nigeria. Lagos: Totan Publishers Limited.

[2] Adesola, A. A. (2005). Resources provision and utilization, Mathematics ability and learning environment as prediction of learning outcomes in undergraduate practical Geography. Unpublished Ph. D Thesis, University of Ibadan, Ibadan.

[3] Adesoji, F. A. (1999). Mock examination results and students gender as correlates of performances in the school certificate examinations in Mathematics. African Journal of Educational Research 5(1), 101-107.

[4] Ahievboloria, J. E. V. (2005). A comparative study of manpower and physical facilities in tertiary institutions in Delta State. Unpublished M. Ed. Dissertation. Delta State University, Abraka, Nigeria.

[5] Ajayi, I. A. and Ayodele, J.B. (2001). Introduction to Educational Planning, Administration and Supervision. Lagos, YPPS.

[6] Ajayi, I. A. and Ayodele, J. B. (2002). Fundamental of Educational Management. Ado-Ekiti: Greenline Publishers.

[7] Ajila, C. and Olutola, A. (2000) Impact of parent socioeconomic status on University students' academic performance. Ife Journal of Educational Studies, 7(1), 31-39

[8] Akinfolarin, C. A. (2008). Resources utilization in vocational and technical education in College of Education, South West Nigeria. Unpublished Ph.D Thesis, University of Ado-Ekiti, Ado-Ekiti, Nigeria.

[9] Akinsanya, O. O. (2008). Differential distribution and civilization of human and material resources on students' academic performance in secondary schools in Ogun State. African Journal for the Study of Educational Issues 4(4), 170176.

[10] Akinwonmi, O. (2006). Differential distribution and utilization of educational resources and academic performance in secondary schools in Ogun State. Unpublished Ph.D Thesis, Olabisi Onabanjo Univeristy, Ago- Iwoye, Nigeria.

[11] Archibong, I. A. and Nja, M. E. (2011). Towards improved teaching effectiveness in Nigerian public universities: Instrument design and validation. Higher Education Studies 1(2), 78- 84.

[12] Ashibi, N. I. (2005). Assessment of the application of testing skills among Secondary schools teachers in Northern Cross River State, Nigeria. Unpublished M. Ed Thesis, University of Calabar, Calabar, Nigeria.

[13] Asikia, O. A. (2010). Academic procrastination in Mathematics: Causes, dangers and implications of counseling for effective learning. International Education Studies 3(3), 205-210.

[14] Ayodele, J. B. and Abiodun, O. O. (2008). The issues of quality assurance in Nigerian universities. Pp. 142-149. In Babalola, J. B. et. al. (Eds.). Towards Quality in African Higher Education. Higher Education Research and Policy Network / The Postgraduate School, University of Ibadan, Ibadan.
[15] Ayodele, J. B. and Ige, M. A. (2012). Teachers' utilization as correlate of students' academic performance in senior secondary schools in Ondo State, Nigeria. European Journal of Educational Studies 4(2), 282-287.

[16] Ayodele, J. B. and Oyewole, B. K. (2012). Repositioning the teaching profession to meet developmental challenges in Nigeria. Mediterranean Journal of Social Sciences 3(3), 47-51.

[17] Bickerstaff, D. (1977). A practical course in education and development. Ibadan: Macmillan Nigeria.

[18] Card, D. and Knieger, A. (1996). School resources and student outcome: An overview of the literature and new evidence from North and South Carolina. Journal of Economic Perspectives $10,31-40$.

[19] Clemens, H. M. and Delke, M. O. (1967). Factors related to reported problems of adolescents. Personnel and Guidance Journal 45, 699-702.

[20] Darling-Hammed, L. (2005). Teachers quality and student achievement: A review of State Policy evidence. Educational Policy Analysis Archive 8(1), 1-44.

[21] Demir, C. E. (2009). Factors influencing the academic achievement of the Turkish urban poor. International Journal of Educational Development 29, 17-29.

[22] Edem, D.A. (1987). Introduction to educational administration in Nigeria. Lagos: Spectrum Books Limited.

[23] Egungun, N.Y. (1992) Human resource development and utilization in Nigeria private enterprises. Pp. 6-12. In Yahaya, A.D. and Akinyele, A. (Eds.). Human resource development and utilization, policies and issues. Administration Staff College of Nigeria, Badagry.

[24] Ekundayo, H.T., Konwea, P.E. \& Yusuf, M. A. (2010). Towards effective time management among lecturers in Nigerian Universities. Journal of Emerging Trends in Educational Research and Policy Studies 1(1), 22-24.

[25] Eweniyi, G. D. (2002). The impact of family structure in university students' academic performance. Ilorin Journal of Education 21, 20-28.

[26] Fabunmi, M., Brai-Abu, P and Adeniji, A. (2007), Class factors as determinants of secondary school student's academic performance in Oyo State, Nigeria. Journal of Social Sciences 14(3), 243-247.

[27] Fabunmi, M. and Okore, A. (2000). Analysis of the relationship between average class size and secondary school academic performance. Africa Journal of Educational Planning and Policy Studies, 1 (2), 107-115.

[28] Ferguson, R. F (2010). Student perception of teaching effectiveness. National Centre for Teacher Effectiveness as the Achievement Gap and Value. Harvard University, Boston, USA.

[29] Fiore, A. (2006). The Now Habit: A strategic program for overcoming procrastination and enjoying guilt-free play. New York: Pengnium Group.

[30] Fuller, B. and Clarke, P. (1994). Railing school effects while ignoring culture? Local conditions and the influence of classroom tools, rules and pedagogy. Review of Educational Research 64,122- 131. 
[31] Gerard, M. (2002). Negative influences of time management. www.cskishore.com/timetips 52. Asp.

[32] Greenwald, R., Hedges, L. V. and Laine, R. (1996). The effect of school resources on student achievement. Review of Educational Research 66, 361-396.

[33] Greewait, J. F. (2002). Managing your time, energy and talent in ministry. New York: Fathers and Brothers of S \& Paul.

[34] Hanushek, E. A. (1997). Assessing the effects of school resources on student performance: An update. Educational Evaluation and Policy Analysis 19(2), 52-58.

[35] Heller, R. and Hindle, T. (1998).Essentials manager's manual. Slovakia: TBB.

[36] Heyman, S. P. and Loxley, W. A. (1983). The effect of primary school quality in academic achievement across 29 high- and low-income countries. American Journal of Sociology 88(6), 1162-1194.

[37] Ibi, M. B. A. (2002). Relationship between educational resources and student academic achievement in Taraba State Senior Secondary Schools. Unpublished M.Ed Thesis, University of Maiduguri, Maiduguri, Nigeria.

[38] Ibukun, W. O., Akinfolarin, C. A \& Alimi, S. O (2011). Correlate of resource utilization and students' learning outcome in Colleges of Education in Southwest Nigeria. International Education Studies 4(3), 178-182.

[39] Ichado, S.M. (1998). Impact of broken home on academic performance of secondary school students in English Language. Journal of Research in Counseling Psychology 4(1), 84- 87.

[40] Ikoh, M. (2007). Classroom variables and senior secondary school students' performance in accessing in Calabar Metropolis. Unpublished PGD Thesis, University of Calabar, Calabar.

[41] Iyamu, E.O.S. (2005). Parents' and teachers' perception of selection as sectors of quality in the curriculum process in Nigeria. International Education Journal 6(1), 96-103.

[42] Imogie, A. I. (2002). Counseling for quality assurance in education. A keynote address delivered on the occasion of $26^{\text {th }}$ Annual Conference of CASSON, University of Benin, Benin City, August, 2002.

[43] Kida, A. A. H. (2004). Relationship between human and material resources and Students academic achievement in Borno State Senior Secondary Schools. Unpublished M. Ed. Thesis, University of Maiduguri, Maiduguri, Nigeria.

[44] Lindahl, M. (2005). Home versus school learning: A new approach to estimating the effect of class size on achievement, Scandinavian Journal of Economics 107(2), 375-374.

[45] Ministry of Education, Science and Technology (2011). Academic performance of Ekiti secondary school students in national examinations for the period 2006-2008. Planning and Research Department, Ekiti State Ministry of Education and Technology, Ado-Ekiti, 2011.

[46] Neglieri, J. A. and Gottling, S. H. (1997). Mathematics instruction and pass cognitive processes: An intervention study. Journal of Learning Disabilities V, 513-520.
[47] Nwadiani, M. (1999). Nigerian students of school time utilization pattern in a period of educational management shift. Indian Journal of Education Management Review 35(2), 155165.

[48] Nzewunwah, P. N. (1995). The effects of single parenthood on the academic performance of students. Unpublished M. Ed Thesis, University of Lagos, Lagos.

[49] Obayan, P. A. (2003). Quality education of basic education. A comparative model. Nigeria Journal of Education Research and Evaluation. 1(4), 87-89.

[50] Olaniyi, W. O. (1998). Conceptual approach to educational administration. Ondo: Patrick Ade Printing Press.

[51] Oluwatayo, A. O. and Adebule, S. O. (2012). Assessment of teaching performance of student -teachers on teaching practice. International Education Studies 5(5), 109-115.

[52] Omojola, I.O. (2010). Influence of time management on Administrative effectiveness in higher institutions in Ekiti State, Nigeria. Unpublished M. Ed Thesis, University of Ado-Ekiti, Ado-Ekiti, Nigeria.

[53] Oyewole, B. K. (2008). Instructional supervision and job performance among secondary school teachers in Ekiti State, Nigeria, Unpublished $\mathrm{Ph}$. D. Thesis, Adekunle Ajasin University, Akungba-Akoko, Nigeria.

[54] Pollard, A. (2006). Reflective teaching, $2^{\text {nd }}$ Edition, British Library, London.

[55] Rivlcin, S. G., Hanushek, E. A. \& Kain, J, F. (2005). Teachers, schools and academic achievement. Econometrica 73(2), 417458 .

[56] Savasci, H. S. and Tomul, E. (2013). The relationship between educational resources of school and academic achievement. International Education Studies 6(4), 114-123.

[57] Tenibiaje, D. J. (2009). Influence of family size and family birth order on academic performance of adolescents in higher institution. Pakistan Journal of Social Sciences 6(3), 110-114.

[58] Thomas, W. J. \& John, E. S. (1977). Managing today and tomorrow. Philippine: Addision-Wisely Publishing Company Inc.

[59] Tomul, E. \& Savasci, H. S. (2012). Socioeconomic determinants of academic achievement. Educational Assessment, Evaluation and Accountability 24(3), 175-187.

[60] Ukeje, B. O., Okorie, N. G. \& Nwagbora U. A. (1992). Education Administration, Theory and Practice, Totan Publishers, Lagos.

[61] Ushie, M. A., Emaka, J. O., Ononga, G. I. and Owolabi, E. O. (2012). Influence of family structure on students' academic performance in Agege Local Government Area, Lagos State, Nigeria. European Journal of Educational Studies 4(2), 177189.

[62] Wiseman, S. (1973). The educational obstacles race: Factors that hinder public progress. Educational Research 15(2), 8793. 